\title{
Evaluation of the success of supraclavicular blockade performed under general anesthesia in arthroscopic surgery of the shoulder by using Perfusion Index
}

\section{Artroskopik omuz cerrahisinde genel anestezi altında yapılan supraklaviküler blokajın başarısının Perfüzyon Indeksi kullanılarak değerlendirilmesi}

\author{
Ayşegül Ceylan ${ }^{* *}\left(\mathbb{D}\right.$, Mehmet Burak Eşkin ${ }^{2}$ \\ ${ }^{1}$ Anesthesiologist, Dpt. of Anaesthesiology and Reanimation Gülhane Training and Research Hospital, Ankara, Turkey \\ ${ }^{2}$ Assistant Professor Dr. Anesthesiologist, Dpt. of Anaesthesiology and Reanimation Gülhane Training and Research Hospital, Ankara, \\ Turkey \\ * Corresponding author: Ayşegül Ceylan E-mail: ceylan.ayegl@gmail.com ORCID: 0000-0003-2816-2629 \\ Received: 28 June 2019 Accepted: 17 September 2019
}

\begin{abstract}
Aim: Supraclavicular blockade under ultrasonic-guidance has recently increased its popularity and is an alternative to anesthesia and analgesia in arthroscopic surgery of the shoulder.

The aim of this study is to evaluate the effectiveness of the perfusion index (PI) which indicates the increase in peripheral perfusion of the upper extremity in determining the success of single dose supraclavicular nerve block under general anesthesia.
\end{abstract}

Material and Methods: The PI was measured non-invasively with pulse-oximetry probe (Masimo Corp, Irvine, CA, USA) from the fingers at the same and opposite sides of blockade at the beginning, 5th, 10th, 20th, 30th minutes, postoperatively and in post anesthesia care unit (PACU). The pain scores were recorded in the PACU, post-operatively and at the $1 \mathrm{st}, 12 \mathrm{th}$, and 24th hours. Preoperative and postoperative arterial pressures and pulse rates were monitored and recorded at the beginning, 5th, 10th, 20th, 30th minutes, postoperatively and in PACU.

Results: Mean PI change rate measured at the beginning was significantly higher than those measured in all other times and when compared to the initial PI change rate, the rates of change were found to increase significantly in the 5th, 10 th and 20th minutes $(p<0.001)$. Mean arterial pressure and mean heart rate values measured at the beginning were significantly higher than those measured at all times $(p<0.001)$. No intraoperative injection of fentanyl or infusion of remifentanyl were 
performed. The patients had no additional requirement of narcotics during the 24-hours follow-up period postoperatively, except for routine analgesics.

Conclusions: We think that peripheral blocks; especially in multimodal anesthetic applications, have intraoperative analgesic activity in addition to postoperative efficacy. They may also contribute to hemodynamic stabilization without narcotic requirement. The success of the blockade can reliably be evaluated by the PI measurement.

Keywords: supraclavicular block, perfusion index

\section{öz}

Amaç: Ultrason kılavuzluğu altındaki supraklaviküler blokaj son zamanlarda popülerliğini arttırmıştır ve omuz artroskopik cerrahisinde anestezi ve analjeziye alternatif olmaktadır.

Bu çalışmanın amacı, genel anestezi altında tek doz supraklaviküler sinir bloğunun başarısını belirlemede üst ekstremitenin periferal perfüzyonundaki artışı belirten Perfüzyon İndeks (PI) değerinin etkinliğini değerlendirmektir.

Gereç ve Yöntemler: PI değeri blokaj öncesi başlangıçta, blokajdan sonraki 5., 10., 20., 30. dakikalarda ve anestezi sonrası bakım ünitesinde (PACU) blokajın aynı ekstremite tarafından ve diğer tarafındaki parmaklarından nabız-oksimetri probu (Masimo Corp, Irvine, CA, ABD) ile non invazif şekilde ölçülmüştür. Ağrı skorları ameliyat sonrası ve 1., 12. ve 24. saatlerde PACU'da kaydedildi. Ameliyat öncesi ve ameliyat sonrası arter basınçları ve nabızları, ameliyat öncesi, ameliyat sonrası ve PACU'da 5., 10., 20., 30. dakikalarda izlendi ve kaydedildi.

Bulgular: Başlangıçta ölçülen ortalama PI değişim oranı, diğer tüm zamanlarda ölçülenlerden anlamlı derecede yüksekti ve ilk PI değişim oranı ile karşılaştırıldığında, değişim oranlarının 5., 10. ve 20. dakikalarda anlamlı şekilde arttığı bulundu $(p<0,001)$. Başlangıçta ölçülen ortalama arter basıncı, ortalama kalp atış hızı değeri diğer zamanlarda ölçülenlerden anlamlı derecede yüksekti $(p<0,001)$. Hiçbir intraoperatif fentanil enjeksiyonu veya remifentanil infüzyonu gerçekleştirilmedi. Hastaların postoperatif 24 saatlik takiplerinde rutin analjezikler dışında ek narkotik gereksinimi yoktu.

Sonuç: Periferik bloklar özellikle multimodal anestezik uygulamalarda postoperatif etkinliğin yanı sıra intraoperatif analjezik aktiviteye sahiptir, narkotik gereksinimi olmadan hemodinamik stabilizasyona katkıda bulunabilirler ve PI ölçümü blokajın başarısının değerlendirilmesinde güvenilir bir yöntem olabilir.

Anahtar kelimeler: supraklaviküler blok, perfüzyon indeksi

\section{INTRODUCTION}

Today, the use of arthroscopic techniques in surgery of the shoulder has increased [1]. In the postoperative period, a large number of patients have severe pain after arthroscopic surgery of the shoulder (ASS) and require large amounts of opioids that may affect perioperative results $[2,3]$.

Ultrasound-guided peripheral nerve blocks are commonly used for anesthesia and analgesia in surgery of upper extremity [4]. The blocks are performed as single injection or continuous nerve block in procedures for upper extremity (such as flap shifting, reimplantation procedures) in which perfusion is desired to be increased, especially in the postoperative period $[5,6]$.
Supraclavicular blockade (SCB) under ultrasonic-guidance has recently increased its popularity [7] and is an alternative to anesthesia and analgesia in ASS [8]. SCB is performed in a more distal region that carries lesser anatomical risk for neurological damage and has lesser rates of hemidiaphragmatic paresis $[9,10]$, Hoarseness or Horner's syndrome [11,12].

After a successful peripheral nerve blockade, sympathetic, sensorial and motor blocks occur, respectively. The depth of sympathetic block after brachial plexus blockade can be evaluated by detection of pain and physiological changes such as vasodilation, changes in blood flow, capillary filling time, skin temperature and pin prick test [13-15]. These methods to evaluate sympathetic blockade can be used in awake and compliant patients. However, they are time- 
Table 1. Demographic structure and other measurement values of patients

\begin{tabular}{|c|c|c|}
\hline \multicolumn{2}{|c|}{ Age } & $42.52 \pm 14.33$ \\
\hline \multicolumn{2}{|c|}{ VKI } & $23.67 \pm 1.91$ \\
\hline \multicolumn{2}{|c|}{ Hb } & $12.26 \pm 1.68$ \\
\hline \multicolumn{2}{|c|}{ Operation Time } & $100.90 \pm 31.14$ \\
\hline \multicolumn{2}{|c|}{ Surgical Start Time } & $22.00 \pm 3.64$ \\
\hline \multirow{2}{*}{ Sex } & Female & $\mathrm{n}=17,34 \%$ \\
\cline { 2 - 3 } & Male & $\mathrm{n}=33,66 \%$ \\
\hline \multirow{2}{*}{ ASA } & 1 & $\mathrm{n}=32,64 \%$ \\
\cline { 2 - 3 } & 2 & $\mathrm{n}=18,36 \%$ \\
\hline \multirow{3}{*}{ PostopVAS } & 0 & $\mathrm{n}=9,18 \%$ \\
\cline { 2 - 3 } & 1 & $\mathrm{n}=22,44 \%$ \\
\cline { 2 - 3 } & 2 & $\mathrm{n}=28,56 \%$ \\
\cline { 2 - 3 } & & \\
\hline
\end{tabular}

consuming, subjective, variable depending on the environmental conditions and require complex equipment.

The perfusion index (PI) is a numerical value indicating the ratio between pulsatile and non-pulsatile blood flow which is automatically measured from the finger via a pulse oximeter and it is a non-invasive monitoring method showing increased peripheral perfusion $[16,17]$. In case of vasodilatation, a relative increase in pulsatile flow leads to an increase in $\mathrm{PI}$. $\mathrm{PI}$ is a non-invasive monitoring method that gives information about perfusion by using pulse oximetry waves [18]. It has been reported that non-invasive measurement of perfusion index is effective to determine the success of brachial plexus blocks $[19,20]$.

The aim of this study is to evaluate the effectiveness of the $\mathrm{PI}$ which indicates the increase in peripheral perfusion of the upper extremity in determining the success of single dose supraclavicular nerve block under general anesthesia.

\section{MATERIAL AND METHOD}

After the approval of the local Ethical Committee,

\section{Patient Selection}

Female or male 50 patients aged between 18 and 60 years old and with ASA 1-2 risks who were planned to undergo ASS in the operating room of orthopedics in Gulhane Training and Research Hospital were included in this retrospective study.

\section{Exclusion Criteria}

Inadequate peripheral nerve blockade, performing another anesthetic method, signs of infection in the site of blockade and presence of bleeding diathesis, peripheral vascular disease, diabetes mellitus or peripheral neuropathy.

\section{The Procedure}

Standard monitoring was carried out for the patients in the operating room. An intracath was inserted over the hand at the non-surgical side and physiologic saline infusion was started with a rate of $100 \mathrm{ml} / \mathrm{hr}$. After 3 minutes of preoxygenation, general anesthesia was performed. The patients were administered $3 \mathrm{mg} / \mathrm{kg}$ of propofol, $0.5-1$ $\mathrm{mg} / \mathrm{kg}$ of fentanyl and $0.6 \mathrm{mg} / \mathrm{kg}$ of esmeron intravenously and then were maintained with sevoflurane after intubation with the MAC 1-1.5. In volume-controlled mode, patients were respirated 12 times/min at a volume of $0.5-0.8 \mathrm{ml} / \mathrm{min}$ to have a $\mathrm{CO}_{2}$ value of 30-35. Following general anesthesia, local anesthetic ( $15 \mathrm{ml}$ 5\% Bupivacaine $+5 \mathrm{ml} 2 \%$ Lidocaine) was injected for nerve blockade at the operational side with a 22-gauge stimulated needle (Unipex Nanoline TM pajunk, Geisingen, Germany) by using an $8-14 \mathrm{mHz}$ linear ultrasonic probe (EDGE ${ }^{\circledast}$ ultrasound machine, Sonosite inc. Bothell, Washington, USA).

The supraclavicular artery was identified in the supraclavicular fossa. Brachial plexus was observed over and on the lateral of the artery. A total of $20 \mathrm{ml}$ was injected around the plexus under control by applying negative pressure after each $5 \mathrm{ml}$ injection. Five minutes after the injection, it was confirmed by ultrasound that the local anesthetic material completely surrounded the plexus. In patients whose intraoperative spontaneous respiration came back, $10 \mathrm{mg}$ esmeron, injection was planned, if needed. In case the heart rate (HR) or mean arterial pressure (MAP) increased more than $20 \%$ of the baseline values, 1 $\mu \mathrm{g} / \mathrm{kg}$ of fentanyl was planned to be administered intravenously.

\section{Post-procedural Care}

The perfusion index was measured non-invasively with pulse-oximetry probe (LNCS adult adhesive sensor connected to Masimo SET_Radical-7TM Pulse CO-Oximeter; Masimo Corp, Irvine, CA, USA) from the fingers at the same and opposite sides of blockade at the beginning, $5^{\text {th }}, 10^{\text {th }}$, $20^{\text {th }}, 30^{\text {th }}$ minutes, postoperatively and in post anesthesia care unit (PACU).

Pre- and post-operative arterial pressures and pulse rates were monitored and recorded at the beginning, 5th, 10th, 20th, 30th minutes, postoperatively and in PACU.

The pain scores were recorded in the PACU, post-operatively and at the $1 \mathrm{st}, 12 \mathrm{th}$, and 24th hours. Postoperative pain was assessed by using a 10 points visual analog scale (VAS) ranging from 0 point (no pain) to 10 points (the worst pain that can be felt). In the first 24 hours postoperatively, an anti- 
Table 2. PI index values change according to the time

\begin{tabular}{|c|c|c|c|}
\hline$(n=50)$ & Mean \pm SS & Test Statistic & The source of the difference $* * * * *$ \\
\hline Beginner (1) & $0.002 \pm 0.113$ & \multirow{7}{*}{$\begin{array}{c}V=0.984^{*} \\
F=464.360^{* *} \\
P<0.001^{* * *} \\
\eta 2=0.984^{* * * *}\end{array}$} & \multirow{7}{*}{$\begin{array}{c}1-2,1-3,1-4,1-5,1-6,1-7 \\
2-3,2-4,2-5,2-6,2-7 \\
3-4,3-5,3-6,3-7 \\
P<0.001\end{array}$} \\
\hline 5. minute (2) & $0.648 \pm 0.398$ & & \\
\hline 10. minute (3) & $2.482 \pm 1.767$ & & \\
\hline 20. minute (4) & $4.886 \pm 1.940$ & & \\
\hline 30. minute (5) & $4.856 \pm 1.940$ & & \\
\hline Postop (6) & $5.128 \pm 1.650$ & & \\
\hline PACU (7) & $5.252 \pm 1.389$ & & \\
\hline \multicolumn{4}{|c|}{ Mauchly'sSphericity Test Statistic $\mathrm{W}=0.001, \mathrm{X} 2=314.746, \mathrm{P}<0.001, \mathrm{df}=20$} \\
\hline \multicolumn{4}{|c|}{ The assumption of Sphericity was not met. } \\
\hline \multicolumn{4}{|l|}{ * Pillai's Trace test statistics value } \\
\hline \multicolumn{4}{|l|}{ ** F test statistics value. } \\
\hline \multicolumn{4}{|c|}{ *** The mean difference is significant at the 0,05 level. $(P<0.05)$} \\
\hline \multicolumn{4}{|c|}{ **** Partial Eta-Square value. } \\
\hline
\end{tabular}

inflammatory drug and $1000 \mathrm{mg}$ paracetamol three times a day was given, if required. Requirement for additional narcotics were recorded. Tramadol $1 \mathrm{mg} / \mathrm{kg}$ was planned to be administered intravenously if the pain score was more than 3 points.

The difference in PI values obtained from successful blocks was compared with the PI values of the opposite extremity.

\section{Statistical Analyses}

Data were analyzed with IBM SPSS Statistics version 21 (IBM SPSS Inc, Chicago, IL) package program. Mean and standard deviation were used for continuous variables while frequency and percentage were used for categorical variables. Kolmogorov-Smirnov test was used to determine the consistency of continuous variables with the normal distribution. PI change rates and the changes in heart rate and mean blood pressure which were measured in seven different times (at the beginning, 5th, 10th, 20th and 30th minutes, postoperative period and in the PACU) were evaluated by Repeated Measure ANOVA. The homogeneity of variance and the assumption of sphericity was assessed by with the Levene's test and Mauchly's Sphericity Test Statistic, respectively. MANOVA was used because the hypothesis of sphericity was not met. The analysis was evaluated by Pillai's Trace test. Bonferroni adjustment was used as multiple comparison test. Clinical significance was determined by partial-eta-square $(n 2)$ for ANOVA and according to the threshold values recommended by Cohen (1988), 0.0099 small, 0.0588 medium, and 0.1888 large effect. A $P$ value $<0.05$ was considered statistically significant.

\section{RESULTS}

Our study included 50 patients. Of the participants. 24 were female and 26 were male. Mean age, mean body mass index (BMI) mean hemoglobin $(\mathrm{Hb})$ value, operative time, starting

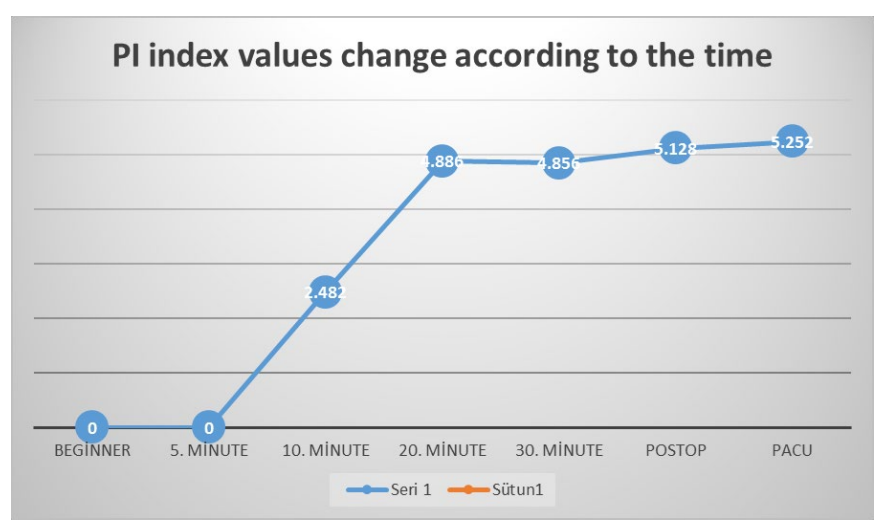

Figure 1. PI index values change according to the time

time of surgery after blockade and postoperative VAS values $\mathrm{t}$ Thirty-two patients were in ASA-1 risk group and postoperative VAS score was 1 and 2 points in 22 and 28 patients, respectively.

Mean PI change rate measured at the beginning was significantly higher than those measured in all other times and when compared to the initial PI change rate, the rates of change were found to increase significantly in the 5th, 10th and 20th minutes $(p<0.001)$. At the other times (30 minutes, postoperative and PACU), PI maintained its high value when compared to the initial value; however no significant increase was observed (Table 2, Figure 1). Clinical significance indicates a high level of efficacy according to the limit values proposed by Cohen $(\eta 2=0.984>0.1397)$.

The mean of mean arterial pressures (MAP) was found to change significantly in time $(P<0,001)$. Mean MAP value measured at the beginning was significantly higher than those measured at all times $(p<0.001)$, (Table 3$)$. Clinical significance indicates a high effect level according to Cohen's recommended limit values ( $n 2=0.656>0.1377$ ). Clinical significance indicates a high level of efficacy according to the limit values proposed by Cohen ( $\eta 2=0,656$ $>0,1379$ ), (Table 3). 
Table 3. Effects of Time on Mean Arterial Presure

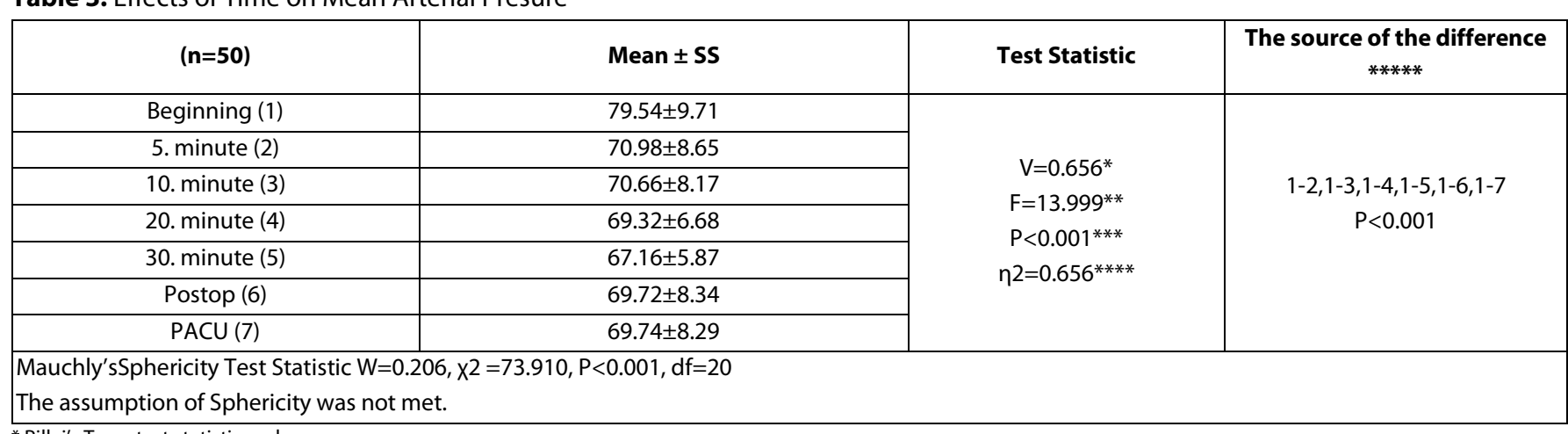

* Pillai's Trace test statistics value

** F test statistics value.

*** The mean difference is significant at the 0,05 level. $(P<0.05)$

**** Partial Eta-Square value.

***** Bonferroni adjustment was used as post-hoc test.

Table 4. Effects of Time on Heart Rate

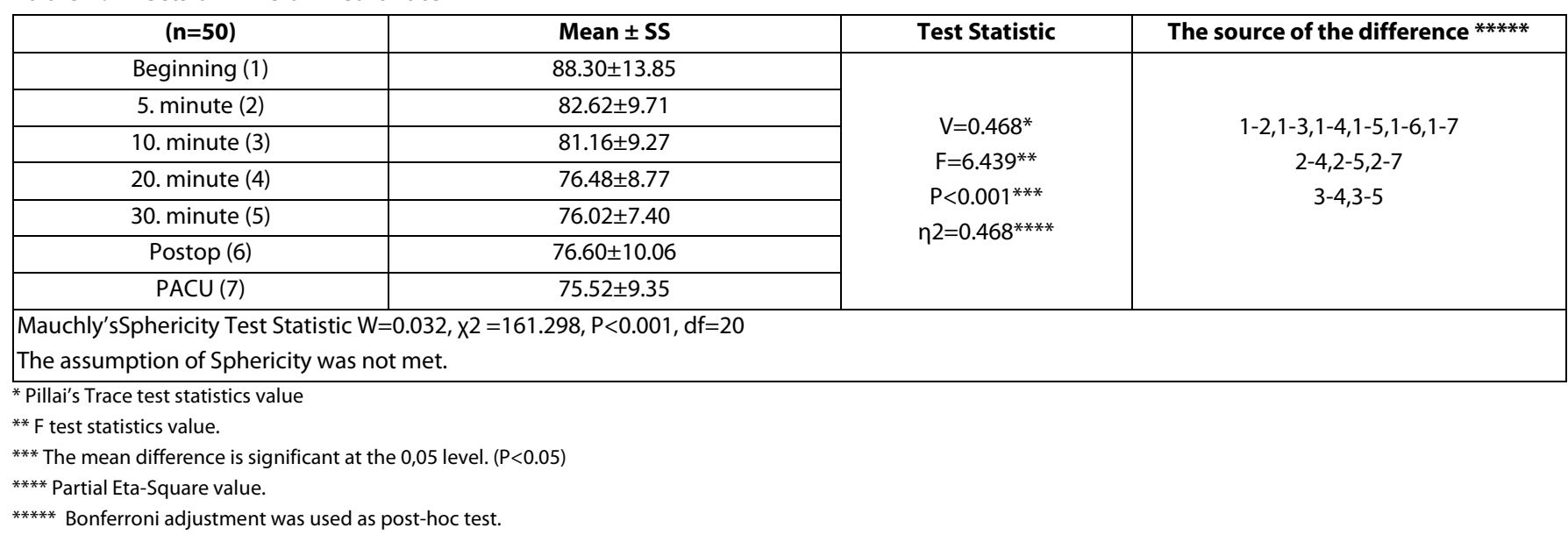

The mean heart rate (HR) was found to change significantly in time $(P<0.001)$. Mean $H R$ values measured at the beginning were significantly higher than those measured at of all times $(\mathrm{P}<0.001)$. Mean HR value measured at the 5 th minute was significantly higher than those measured at the 20th, 30th minutes and in the PACU $(P<0.001)$. We also found that mean HR values at the 20th and 30th minutes were significantly lower than those measured at the 10th minute $(P<0.001)$, (Table 4). Clinical significance indicates a high level of efficacy according to the limit values proposed by Cohen for the partial eta-square $(\eta 2=0.468>0.1379)$.

No intraoperative injection of fentanyl or infusion of remifentanyl were performed after initial administration of narcotics. The patients had no additional requirement of narcotics during the 24-hours follow-up period postoperatively, except for routine analgesics.

\section{DISCUSSION}

In ASS, patients' desire for general anesthesia is common. SCB is effective in reducing intra-operative narcotics requirement and can be used as an advantageous method with its pain relieving property in patients who underwent surgery of the shoulder with general anesthesia in which patients' compliance and comfort is difficult to achieve. The success of the blockade applied to the patients under general anesthesia can be determined by the change rate of PI index.

In our study, general anesthesia was performed in patients undergoing arthroscopic surgery of the shoulder in the orthopedics clinic considering that blockade of brachial plexus + sedation would not be sufficient in terms of patient compliance and comfort. After sleeping, USG-guided supraclavicular blockade was performed by using $20 \mathrm{ml}$ of local anesthetic. Success of the blockade was monitored by PI index, HR and MAP. PI index values of the blocked extremity were compared to the opposite extremity. PI index values of the patients significantly increased after the blockade from the $5^{\text {th }}$ minute until the $20^{\text {th }}$ minute when compared to the initial values. was statistically application. It remained stable at the 30th minute and at the following measurements; no significant increase was observed. 
Laryngoscopy and endotracheal intubation lead to catecholamine release via the sympathoadrenergic system. Increase in catecholamine levels may cause elevations in heart rate and blood pressure $[21,23]$. HR was significantly higher at the $5^{\text {th }}$ and $10^{\text {th }}$ minutes when compared to the initial values while it was measured to be significantly lower than the baseline values at the other times. This period was consistent with the time to full blockade and time to the initiation of surgery. The mild tachycardia at the first $5^{\text {th }}$ and $10^{\text {th }}$ minutes was attributed to the intubation response and preoperative dehydration due to fasting.

MAP values were measured to be lower than baseline levels at all times. There was no increase in hemodynamic parameters with painful stimulation during the surgery. The mean time to surgical onset was 22 minutes.

In our patients, we monitorized the post-blockade hemodynamic responses and PI changes at the beginning of and during the surgical procedure. The efficacy of motor and sensory blockade was controlled by various methods in the PI studies performed for peripheral blocks in awake patients. Our study was performed under general anesthesia. According to the PI index values, the block can be accepted "adequate" after the 20th minute (starting from the 5th min).

After the first 20 minutes, hemodynamic parameters of the patients were stabilized and there was no increase in blood pressure and pulse rate during surgical stimulus.

Systemic hemodynamic parameters are not affected in the blockade of peripheral nerves of upper extremity [3,24-26]. Therefore, they are important in balanced anesthetic procedures. In our patients, no additional narcotics or remifentanil infusion were administered intraoperatively except for fentanyl for the induction. The fact that we did not administer remifentanyl infusion would have helped to compensate for bradycardia and hypotension in terms of hemodynamic stability.

Postoperative all patients had VAS scores of 1 and 2 points. No patients required narcotics except routine paracetamol + NSAIDs.

Previously, supraclavicular blockade was not preferred for surgery of the shoulder because of the proximity of the brachial plexus to pleura and especially the complication of pneumothorax $[27,28]$. before the use of USG. In a previous large-scale study, the rate of pneumothorax was reported as $0 \%$ after ultrasound-guided supraclavicular block for surgery of the upper extremity in 510 patients [7]. USG minimizes the risk of pneumothorax due to the possibility of visualizing the pleura during supraclavicular blockade [11].
A potential advantage of the supraclavicular approach is the easier visualization of the brachial plexus in the supraclavicular fossa [11]. In the present study, we observed no clinical findings of pneumothorax in our patients. In order to avoid unnecessary exposure of radiation, chest radiograms were not routinely performed to exclude pneumothorax. Guidance of USG provides safer conditions and decreases the concern of pneumothorax [28].

Recent studies have investigated the efficacy of SCB on surgery of the shoulder [29-31]. SCB has been shown to be an effective alternative to postoperative analgesia in surgery for shoulder instability $[11,29]$. There has been some concern regarding the analgesic efficacy of SCB would be inadequate in blocking the suprascapulary nerve (primary nerve of the joint of the shoulder) which stems from upper truncus of the brachial plexus (C4-5-6 nerve roots). A cadaveric study [32]. showed that the dye which was administered under US guidance into the supraclavicular region via anterior approach spread towards the brachial plexus. However, anatomical studies using US and computed tomography revealed that local anesthetics injected for supraclavicular blockade spread between the anterior and medial scalene muscles [33].

In a successful brachial plexus blockade, vasodilation occurs in the extremity [34]. There is a relative increase in pulsatile flow due to vasodilation. Massimo calculates the PI value by rating the pulstatile and non-pulstatile pulses. In various studies evaluating PI as an indicator of peripheral perfusion, it has been reported that basal measurements of the PI may show high variability $[14,35]$.

Kuş et al. compared the PI values of an infraclavicular plexus blockade with a non-blocked arm in patients undergoing orthopedic surgery, and reported that PI was an effective method in determining the success of a blockade within the first 10 minutes [18]. PI index was reported to change significantly at the fifth minute after a supraclavicular blockade. A. Abdelnasser et al. reported that PI may be useful in determining the success of a supraclavicular blockade in patients undergoing orthopedic surgery [36]. Yamazaki et al. [37]. reported that PI was effective in demonstrating the sympathetic blockade efficacy of the sympathetic ganglion blockade.

Sebastiani A. et al. have reported that PI index values changed significantly and increased gradually from the $5^{\text {th }}$ min to the $15^{\text {th }}$ min after successful interscalene blockade. PI can be accepted as an objective measure in evaluation of the blockade. 
In previous studies, the rate of increase in perfusion index was found to be effective in evaluating block success in awake patient; however no any article concerning the availability of PI index in determining the success of the blockade in patients under general anesthesia has been published yet.

\section{Conclusion}

According to the results of our study we think that peripheral blocks; Especially in multimodal anesthetic applications, have intraoperative analgesic activity in addition to postoperative efficacy, they may contribute to hemodynamic stabilization without narcotic requirement and $\mathrm{PI}$ measurement can be a reliable method in evaluating the success of the blockade.

\section{DECLARATION OF CONFLICT OF INTEREST}

The authors received no financial support for the research and/or authorship of this article. There is no conflict of interest.

\section{REFERENCES}

1. Kavaja L, Malmivaara A, Lahdeoja T, et al. Shoulder Capsular Surgery in Finland Between 1999 And 2008: A Nationwide Register Analysis. Scandinavian journal of surgery. 2018. (doi: 10.1177/1457496917748219).

2. Huang R, Wang S, Wang $Y$ et al. Systematic Review of All -Arthroscopic Versus Mini -Open Repair of Rotator Cuff Tears: A Meta -Analysis. Scientific Reports. 2016;6:228-57.

3. Fredrickson MJ, Krishnan S, Chen CY. Postoperative analgesia for shoulder surgery: a critical appraisal and review of current techniques. Anaesthesia. 2010;65:60824

4. Hussain N, Goldar G, Ragina N, et al. Suprascapular and Interscalene Nerve Block for Shoulder Surgery: A Systematic Review and Meta-analysis. Anesthesiology. 2017;127:998-1013.

5. Su HH, Lui PW, Yu CL, et al. The effects of continuous axillary brachial plexus block with ropivacaine infusion on skin temperature and survival of crushed fingers after microsurgical replantation. Chang Gung medical journal. 2005;28:567-74.

6. Loland VJ, Ilfeld BM, Abrams RA, et al. Ultrasound-guided perineural catheter and local anesthetic infusion in the perioperative management of pediatric limb salvage: a case report. Paediatric Anesthesia. 2009;19:905-7.
7. Perlas A, Lobo $\mathrm{G}$, Lo $\mathrm{N}$, et al. Ultrasound guided supraclavicular block: results of 510 consecutive cases. Regional Anesthesia and Pain Medicine. 2009;34:171-6

8. Neal JM, Gerancher JC, Hebl JR, et al. Upper extremity regional anesthesia: essentials of our current understanding, 2008. Regional Anesthesia and Pain Medicine 2009;34:134-70.

9. Ghodki PS, Singh ND. Incidence of hemidiaphragmatic paresis after peripheral nerve stimulator versus ultrasound guided interscalene brachial plexus block. Journal of Anaesthesiology Clinical Pharmacology 2016;32:177-81.

10. Koh WU, Kim HJ, Park HS, et al. A randomised controlled trial comparing continuous supraclavicular and interscalene brachial plexus blockade for open rotator cuff surgery. Anaesthesia. 2016;71:692 -9.

11. Liu SS, Gordon MA, Shaw PM, et al. A prospective clinical registry of ultrasound -guided regional anesthesia for ambulatory shoulder surgery. Anesthesia Analgesia 2010;111:617-23.

12. Brull R, McCartney CJ, Chan VW, et al. Neurological complications after regional anesthesia: contemporary estimates of risk. Anesthesia Analgesia. 2007;104:96574.

13. Hasanin A, Mukhtar A, Nassar H. Perfusion indices revisited. J Intensive Care. 2017;5:24.

14. Lima AP, Beelen $P$, Bakker J. Use of a peripheral perfusion index derived from the pulse oximetry signal as a noninvasive indicator of perfusion. Critical Care Medicine. 2002;30:1210-3.

15. Paul D. Predicting successful supraclavicular brachial plexus block using pulse oximeter perfusion index: is it really an objective outcome? British Journal of Anaesthesia. 2018;120:405-6.

16. Hermanns $H$, Werdehausen $R$, Hollmann MW, et al. Assessment of skin temperature during regional anaesthesia-What the anaesthesiologist should know. Acta Anaesthesiologica Scandinavica. 2018. (doi: 10.1111/aas.13176).

17. Ode K, Selvaraj S, Smith AF Monitoring regional blockade. Anaesthesia. 2017;1:70-5.

18. Kus A, Gurkan Y, Gormus SK, et al. Usefulness of perfusion index to detect the effect of brachial plexus block. The Journal of Clinical Monitoring and Computing 2013;27:325-8. 
19. Nakatani T, Hashimoto T, Sutou l, et al. Retention of finger blood flow against postural change as an indicator of successful sympathetic block in the upper limb. 2017;10:475-9.

20. Goldman JM, Petterson MT, Kopotic RJ, et al. Masimo signal extraction pulse oximetry. The Journal of Clinical Monitoring and Computing. 2000;16:475-83.

21. Kovac AL. Controlling the hemodynamic response to laryngoscopy and endotracheal intubation. The Journal of Clinical Anesthesia 1996;8:63-79.

22. Bedford RF. Circulatory responses to tracheal intubation. In: Eichhorn JH, Kirby RB, Brown DL, editors. Problems in Anesthesia, Philedelphia: Lippincott; 1998;203-10.

23. Derbyshire DR, Chmielewski A, Fell D, et al. Plasma catecholamine responses to tracheal intubation. British Journal of Anaesthesia 1983;55:855-60.

24. Ozzeybek D, Oztekin S, Mavioglu O. Comparison of the haemodynamic effects of interscalene block combined with general anaesthesia and interscalene block alone for shoulder surgery. Journal of International Medical Research. 2003;3:428-33.

25. Kim JH, Song SY, Ryu T, et al. Changes in heart rate variability after sitting following interscalene block. Clinical Autonomic Research. 2015;25:327-33.

26. Simeoforidou M, Vretzakis G, Chantzi E, et al. Effect of interscalene brachial plexus block on heart rate variability. Korean Journal Anesthesiol 2013;64:432-8.

27. Kahverengi DL, Bridenbaugh LD. Kuzenler MJ, et al. editors. Upper extremity somatic block. Neural Blockade in Clinical Anesthesia and Pain Medicine. Philadelphia: Lippincott. 2009;316-342.

28. Kakazu C, Tokhner V, Li J, et al. In the new era of ultrasound guidance: is pneumothorax from supraclavicular block a rare complication of the past? British Journal of Anaesthesia. 2014;113:190-1.

29. Trabelsi W, Ben Gabsia A, Lebbi A, et al. Suprascapular block associated with supraclavicular block: An alternative to isolated interscalene block for analgesia in shoulder instability surgery? Orthopaedics Traumatology Surgery Research 2017;103:77-83.
30. Ryu T, Kil BT, Kim JH. Comparison Between Ultrasound Guided Supraclavicular and Interscalene Brachial Plexus Blocks in Patients Undergoing Arthroscopic Shoulder Surgery: A Prospective, Randomized, Parallel Study. Medicine. 2015;94:1726.

31. Karaman T, Karaman S, Tapar $\mathrm{H}$, et al. Comparison of Ultrasound -Guided Supraclavicular and Interscalene Brachial Plexus Blocks in Postoperative Pain Management After Arthroscopic Shoulder Surgery, Pain Practice. 2018. (doi: 10.1111/papr.12733).

32. Siegenthaler A, Moriggl B, Mlekusch S, et al. Ultrasound guided suprascapular nerve block, description of a novel supraclavicular approach. Regional Anesthesia and Pain Medicine. 2012;37:325-8.

33. Cornish P. Supraclavicular block: new perspectives. Regional Anesthesia and Pain Medicine 2009;34:607-8.

34. Galvin EM, Niehof S, Medina HJ, et al. Thermographic temperature measurement compared with pinprick and cold sensation in predicting the effectiveness of regional blocks. Anesthesia \& Analgesia. 2006;102:598-604.

35. Bergek C, Zdolsek JH, Hahn RG. Accuracy of noninvasive haemoglobin measurement by pulse oximetry depends on the type of infusion fluid. European Journal of Anaesthesiology. 2012;29:586-92.

36. Abdelnasser B, Abdelhamid A, Elsonbaty A, et al. Rady Predicting successful supraclavicular brachial plexus block using pulse oximeter perfusion index A. British Journal of Anaesthesia, 2017;119:276-80.

37. Yamazaki H, Nishiyama J, Suzuki T. Use of perfusion index from pulse oximetry to determine efficacy of stellate ganglion block. Local and Regional Anesthesia. 2012;5:914.

38. Sebastiani A, Philippi L, Boehme S, et al. Perfusion index and plethysmographic variability index in patients with interscalene nerve catheters. Canadian Journal of Anesthesia. 2012;59:1095-101. 